\title{
Violence, Identity and (In)security: Experiencing the Maoist Insurgency in Peru
}

\author{
Fiona Wilson
}

\begin{abstract}
This article argues that the position of political violence in developing countries has changed in the post-Cold War period, from being seen (by some) as a legitimate response to dictatorship to become associated with criminality and delinquency on the one hand and terrorism on the other. This provides a new context for 'identity politics', the definition of which has tended to become narrower and in practice more restrictive, leading to a hardening of 'community' boundaries. Taking the Maoist insurgency in Peru as a case study, the article enquires how identity, violence and security have been lived and understood by people in the Andean region. At the centre is an emblematic narrative of an indigenous schoolteacher who explores connections between his experiences of Peru's agrarian and education reforms, early support and later rejection of political violence, and the way his community envisioned and practised security in response.
\end{abstract}

\section{Introduction}

It is hard to conceive of violence that is not 'identity-based', for violence results when basic ideas of humanity are withdrawn or withheld, the victims 'identified' as dangerous, irrelevant, not belonging or not warranting care. At a societal level, structural violence is perpetuated through neglect, injustice, slow starvation, humiliation, lack of recognition, summed up in broad terms like exclusion, marginalisation, and most recently, being 'superfluous'. This kind of violence has been entangled with essentialisms and politics of identity when justifying why some people remain disqualified or subjected to symbolic violence. Earlier discourses blamed the victim on the grounds of lack of civilisation, being of inferior race, being women, or having been colonised. Later, the rationale of inclusion/exclusion translated and fractured into 'identities' of ethnicity, indigenousness, gender, religion, political ideology, nationality, as well as 'poverty'. Structural violence does not only lead to reactions against an iniquitous system; more often exclusion translates into domestic violence and violence against those who, though not unlike oneself, are considered different in some essential way. Violence defies easy categorisation. Acts of violence are mediated by how they are perceived, where one finds in the eye of the beholder a dichotomy between what is legitimate and illegitimate, permissible and sanctioned. Violence is 'a slippery concept - nonlinear, productive, destructive, and reproductive. It is mimetic ... so we can rightly speak of chains, spirals, and mirrors of violence' (Scheper-Hughes and Bourgois 2004), a continuum of violence. This is one lens through which identity politics, violence and (in)security can be approached. But I want to juxtapose it with another line of thought. This underlines important distinctions in the way violence is labelled by beholders (we look through different lenses) and how it is framed by those actively engaging in and responding to violent situations.

Not long ago, the political language in which violence was couched was very different. There was some consensus between beholder and activist that repressive regimes, whether colonial or national, would some day provoke a revolutionary challenge. Revolution was often depicted as glorious and inevitable, the best way to achieve national liberation in the context of anti-colonial or socialist struggles. Later, armed 
insurrection continued to be celebrated as the means to achieve social justice for the mass of peasants and workers who remained trapped in poverty and exploited by foreign capitalist classes and traitorous local elites. Class struggle aiming at a socialist future was projected through political ideology, and the emancipation it would bring conceived as a collective as well as individual trajectory. The excluded and marginalised would be empowered to break free of their chains, so as to become the makers of their own destinies. Their violence was judged legitimate and their struggles supported internationally, not only by some states but also by intellectuals and solidarity groups on 'the left'. The message spread that against dictatorships and repressive regimes, as found in virtually the whole of Latin America in the 1970s, violence was considered permissible by righteous revolutionaries. The term 'guerrilla' indicated the existence of political organisations dedicated to social revolution, infused with an ideology of nationalism and anti-imperialism often led by young, idealistic, urban intellectuals (Kruijt 2008). But the subsequent failure of revolutionary movements and their parties to inaugurate positive change and the disillusion that followed altered the way political violence was perceived both by beholders and by those intent on practicing it.

In post-Cold War western discourse, globalisation, free markets and cutting back of state power were placed in an ideological context of human rights, 'politics of identity' and 'security' that changed the assessment and associations of legitimate violence. As Kaldor and Luckham (2001) argue, the shift from ideological or politically driven violence to identity-based violence was one of the critical distinguishing features of the 'new' wars. Henceforth, political violence tended to become passé among intellectuals 'even if actively practiced by millions of desperately angry people across the globe' (Scheper-Hughes and Bourgois 2004). Scheper-Hughes and Bourgois claim we are now witnessing a transition from political violence to 'the anomie of delinquent violence in the neo-liberal social order', associated with criminality and interpersonal violence on the one hand and an across-the-board labelling of political violence as 'terrorism' on the other. To take the dramatic case of El Salvador, the peace settlement signed with the FMLN guerrilla movement and end of civil war brought not an end to violence, only a change in its character with the welling-up of gang warfare and criminal activity, giving the country the reputation of being the most violent in the most violent continent on earth.

In the maelstrom of transition from political violence to criminality and 'anomie of delinquent violence', it is not easy to distinguish between relabelling and more substantive changes in the nature and framing of violence through complex connections with globalisation, neoliberalism, free markets and lack of state regulatory power. Changing nomenclature impedes analysis.

Blanket charges of terrorism obscure what can be important differences as well as continuities with political violence. Moving the concept 'politics of identity' to centre stage and placing it in new contexts of terrorism and security also misleads. As in the case of violence, in the labelling and framing of identity politics one can remark a tendency towards narrower, less nuanced, definitions. Earlier, an important aspect of overarching identity at national level was famously expressed by Anderson as the 'imagined' community, the 'community of anonymity', brought into existence primarily by the spread of literacy and print capitalism. However, it has also been argued that the national community as imagined and represented in public discourse offered little room for conceptualising heterogeneity, contestation and fracturing of national identity (Wade 2000). For example, though idealised renderings of peasant culture might find a place in overarching national culture, this did not suffice to 'stitch up' the existing heterogeneity and difference. This led to a central, destabilising, paradox. The supposedly homogenous 'nation' was divided not only by enduring hierarchies of class, race and culture, but also was constituted by a 'country of regions' given different weight in the overall ensemble. Thus in the imagined geography of Peru, the Andean region was depicted as indigenous, uncivilised and backward, in contrast to the modernising white-mestizo coast.

Recently, as Geschiere and Meyer (1998) remind us, it is not accidental that 'identity' has emerged as the central concept when trying to grasp how globalisation is reinforcing the production of cultural difference. In current usage, 'identity' 
marks an attempt to fix boundaries in the ongoing flux of globalisation processes, while at the same time registering nostalgia for a time when it seemed possible to isolate bounded social formations. With globalisation, new associations have been given to the 'politics of identity' that tend to reassert the local, meaning localised communal feelings that were supposedly suppressed in processes of state formation. Identity politics now tends to signal a hardening of boundaries, in which narrowly defined 'communities' are constructed. The claim of shared identity is used to justify separation and to forget earlier times when boundaries mattered less and were more permeable, and when there was greater belief in broader-based 'imagined' communities.

These tendencies have manifold implications for the way the concept and aspiration of human security is understood and practised when we look from below. Here one finds a disturbing picture emerging. If a hardening of national/ social/community boundaries is taking place at the local level and is coupled with the belief that separation on the grounds of shared 'identity' is necessary to ensure security, then the consequences at a broader societal level are disastrous. For fragmentation is antithetical to ever achieving 'security for all'. But how is this playing out in practice? By taking a case study, I want to explore how violence and identity can be connected and how people living with violence are able to manage their security.

\section{Living with political violence}

My aim is to focus on local interpretations of security in the context of political violence in Andean Peru. In the recent civil war, the Communist Party of Peru, Sendero Luminoso, adopted a strategy of terror to bludgeon country people into supporting its fight to bring down the state. In retaliation, the state used extreme brutality to subdue the Maoist-led insurgency. The result was ferocious spirals of violence, rapid descent into a 'culture of impunity' and the worst human rights' abuse at the time in the continent. The Peruvian military portrayed the insurgency in racist terms, stereotyping perpetrators as untrustworthy racial half-castes and the masses they led as violent, uncivilised Indians from the backward Andean region. Peru's Truth and Reconciliation Commission has acknowledged the racism shaping the inequalities of Peruvian society. The narrative of national identity, the imagined community that could bring Peruvians together, was badly flawed. Drinot comments:

The Report laid bare the rotten pillars of Peruvian society like no other analysis, pointing to the 'normalised ideas and behaviour' that underpinned the violent actions of Sendero Luminoso and of the armed forces and the indifference of Peru's 'included' few to the predicament of the 'excluded' many. (Drinot 2006)

Indicative of this was the Commission's finding that some 70,000 Peruvians had suffered violent deaths, double the number previously estimated, just over half at the hands of Sendero and just under half at the hands of the military. The vast majority of those who died were Quechuaspeakers from the Andean region. How was it, asked critical voices, that in the Peruvian nation so many deaths had taken place unnoticed?

Instead of summarising the antecedents and history of the insurgency from when armed struggle began in 1980 until 2003 when the Truth and Reconciliation Commission delivered its Report, I want to trace what political violence and security meant in personal terms. How were these issues lived and portrayed? Before this, I shall comment on methodology and the ambiguity of political violence in the case of Peru.

\subsection{Researching violence and security}

In many contemporary studies in the development/security field, one finds that the social actor has receded from view. Individuals appear as ciphers; perhaps a name is attached to a quotation or testimonial, but these are neither framed nor contextualised. The sound bites tend to be predictable, and almost always spoken from the position of the innocent, or the witness. Respondents seem to follow an agreed script; they reflect an agreed standpoint rather than a personal view. This provides few insights for the researcher to work with. For the more one becomes involved in everyday life, in the lived 'realities' of insurgencies, civil wars and 'postconflict' aftermath, the messier and more ambiguous the picture becomes. It does not help our understanding if complexity is brushed aside through recourse to simplification and stereotyping, or the acceptance of standard binaries (like included/excluded, perpetrators/ 
victims). It becomes impossible at the level of everyday life to draw definitive distinctions between those who act violently, those targeted as recipients of violence, and those who are innocent bystanders or just caught in the middle. Only slowly do complexities come to light, and anomalies emerge.

Representing people and accounting for their actions raise a host of ethical questions. These are especially intense in polarised, politicised, conflict situations where claiming or denying an 'identity' or an action (such as killing, raping or being raped) can be a matter of life and death. Research into violence demands a methodology that is reflexive, dialogic, and open-ended, that is sensitive and respectful to what can and should not be talked about. As Theidon records, in their eagerness to document instances of rape by the military in the Andean region of Ayacucho, some researchers believed they had the right to override the indigenous women's request to let them forget, urging that it was better for them to talk it out (Theidon 2007). 'Research' easily becomes intrusive and extractive, especially for acutely vulnerable people for whom the researcher has little to offer in return.

In the turbulent Central Peruvian Andes of the 1990s which I revisited in the mid-1990s, after an absence of 20 years, I chose to work primarily with schoolteachers, both those who supported and those who opposed Sendero. Many teachers were articulate, keen to reflect on their experiences and gave insightful comments on the wider picture. I focused my enquiry partly on what had occurred in the town, and partly on the situation in rural areas, ${ }^{1}$ some communities having 'resisted' and others, as alleged by the military, having collaborated with Sendero. In the dualistic, polarising terminology characteristic of times of conflict, the choice lay between resistance and subversion, there being no possible 'middle ground'.

\subsection{From political violence to delinquency}

Although extremist in its political ideology and excessively violent in its political practice, at the beginning, Sendero Luminoso modelled itself on the guerrilla. As elsewhere in Latin America, the political message was expressed in a language of class oppositions with the corrupt state considered the enemy. Political doctrine centred on reviving popular nationalism through disentangling the rotten state from the people; glorification of armed struggle; belief in a social order brought through force; and a vaguely specified utopia of a perfect society 'of great harmony'. For those engaging with the party there were also more tangible aspirations, release from a disdained marginalised social position as 'cholos' or half-castes, and the possibility of leading and influencing after the armed struggle had toppled the old regime and installed an egalitarian order in which everybody would be the same.

Sendero had long been linked to the education sector. Its founders were lecturers at the new university of Huamanga in the Andean town of Ayacucho, led by philosophy professor, Abimael Guzman. In the contests between Maoist factions, Sendero failed to take control of popular and peasant organisations, but continued to dominate the education programme at the university and branch of the teachers' union. The party spread by enrolling recruits through networks of schoolteachers, students and graduates from provincial universities. In later years, some 30,000 teachers ( 15 per cent of all teachers) were estimated to be actively supporting Sendero, acting as 'eyes and ears' of the party throughout the country. ${ }^{2}$

The association of Sendero with the education sector went deeper. Peruvian analysts argue that the authoritarianism, symbolic violence and everyday humiliation found in Peruvian schools were mirrored by the authoritarian organisational structure of the party (Ansión 1989; Degregori 1991). Sendero played on the mission and vocation of the schoolteacher, a figure who should be vested with authority, bringing civilisation and eradicating superstition from the backward classes. Through intransigence and ruthlessness, the party displaced rival factions and focused its mobilising and recruiting activities on the young in secondary and higher education. Their idealism and hunger for retribution was channelled into political violence to overthrow the racist system responsible for marginalising them. But political violence and criminal/delinquent violence soon blurred. Sendero's tactics of using terror against the indigenous peasantry and growing tendency to murder 'dissidents' from its own ranks, destroyed whatever claim the party might once have had to be promoting 'legitimate violence' in 
a just revolutionary cause. To elaborate on this, I shall refer to my fieldwork material from the province in Tarma in the Central Andean region.

\subsection{Narrating violence and security in Tarma province}

Sendero ideologues had been proselytising in the Central Andean province of Tarma since the early 1970s. Initially they had met with little success. Activists made their presence felt by throwing home-made bombs, attacking district police stations, hoisting the hammer and sickle flag in public places, and writing ugly graffiti on walls. Party presence became more intense once cadres had infiltrated the local telephone exchange, taken over schools in the rural periphery and ousted political rivals running social welfare programmes. In this region, violence reached a crescendo in the period 1989-92, diminishing abruptly after Abimael Guzman was captured in Lima. The aftershocks were palpable when I returned to Tarma in 1994. Over the next few years in intermittent periods of fieldwork, I talked to some 60 teachers about what had happened to them. Convinced Maoists tended to talk impersonally, in slogans. Most eloquent were teachers who had been on the fringes of Sendero, who acknowledged the party's early appeal and fascination, followed by their disillusion and repudiation of the party's cold calculating violence that broke all acceptable norms. I have selected one emblematic account by a rural teacher of indigenous parentage, who in a graphic way illustrates people's responses to violence and ways of framing these, their lived 'politics of identity', and reasons for supporting and then rejecting Sendero as the party moved into delinquent and criminal violence.

\section{Living identity, violence and security: a rural teacher's account:}

Antonio Quispe was born and brought up on hacienda Maco in the highland periphery of Tarma. ${ }^{3}$ As a child he had attended the tiny primary school located at a distance from the settlement that taught up to third grade. His teacher he remembered as 'white'. He had been rough with the children, hitting them until they learnt, and taught through a militaristic pedagogy of marching and bodily discipline. But the children had benefited, Antonio reflected, as they had been slow and timid; boys learnt to hold their heads up high and shout like men. In the enclosed world of the hacienda, children had been submissive because parents had implanted fear of the supernatural. As Antonio later came to realise, peasant superstition had suited the hacendados well, for it had stopped them from learning 'the truth' and reflecting on the reasons for their slavery and exploitation.

Antonio was obliged to work for the hacienda when he turned 14 years of age. But then came the Agrarian and Education Reforms instigated by the military government of Juan Velasco Alvarado (1969-75) and this brought freedom. Though Maco's owners had been unusually resourceful in modernising agriculture and livestock production, the organisation of production was still based on servile labour relations. ${ }^{4}$ The old 'feudal' system was now swept away, and in its place a cooperative founded. In 1970, of the 122 heads of household who became socios (cooperative members), 37 had been unable to sign their names on official documents. At the insistence of the Agrarian Reform office, an administrator was appointed, a white ingeniero agronomo (agricultural engineer) from the coast who was inexperienced in Andean agriculture and abusive of hacienda Indians. On my first visit to Maco in the mid-1970s, I remember the ridiculing and joking about the administrator that went on behind his back. Thanks to the state's education reforms, Antonio had been able to attend secondary school in a district capital a couple of hours' walk away. Finishing school in 1978, he was immediately appointed as a teacher in a large, well-built school on the central square, the pride of the community. There he joined three urban, mestizo teachers, teaching 54 enrolled children. As the only Quechua speaker, Antonio felt it his duty to despertar a la gente (awaken the people). Before long the urban teachers left and Antonio became headmaster. During the military government, the state had appeared to listen to the claims and wishes of the indigenous peasantry. But this ended abruptly in the late 1970s when the state increasingly adopted the ideology of neoliberalism.

Antonio's political militancy was first channelled into struggles in the cooperative, the conflict between socios and administrator. The administrator left. But in 1982 the cooperative was bankrupt, unable to pay the teachers' salaries and Antonio left to look for teaching posts elsewhere in Tarma province. There he came into contact with revolutionary Maoism and the belligerent political message of the 
teachers' union. He found the class-based analysis of Peru's inequality put forward by the Maoists enlightening, and recognised how he had suffered first-hand the abuse of the hacienda system. With other Quechua-speaking teachers, he developed a hybrid political language where an Andean imagery of darkness and light, being blind then seeing, being ignorant then enlightened, and going through physical suffering in order to learn, was interwoven with Maoist doctrine of class-based exploitation learnt from Marxist manuals available in the towns. Teachers fashioned a discourse on power, violence and retribution, giving fellow comuneros emotive concepts through which to apprehend and make sense of the past.

Although Antonio won respect as leader and defender of his community, he felt he had been denied the authority due to a teacher on grounds of race. Proof, in his eyes, was that he had never managed to complete a university degree (in education) begun 20 years before. The conclusion he drew was that even the educated from ex-haciendas and indigenous communities were treated as second-class citizens; they were cholos, a derogatory term coined by a racist external world. A phrase used by Antonio and many others teaching in their home communities was: 'you can never be a prophet in your own land' - their familiarity with and embeddedness in peasant ways meant they could achieve neither authority nor social mobility. But the promise held out by Sendero was that by joining the party and espousing its ruthless doctrine, they could.

At first, Antonio was greatly impressed by Sendero and its intellectual leader, Guzman. He accepted that the revolutionary struggle had been launched on behalf of poor people like himself. The first party cadres who showed up on Maco he found worthy of respect. They were well-educated, spoke perfect Spanish, knew the region, seemed to care about children's welfare; in sum, they conducted themselves like benevolent urban teachers. He was tempted to join them, for he identified with their message of social justice and a new political order swept clean of dirt and corruption. But he did not. In hindsight, he rationalised that he could not leave his suffering community. Like the majority of rural communities, the people of Maco chose a strategy of coexistence; they would wait and see what Sendero cadres offered. A few years later, sympathy for Sendero evaporated. Antonio moved from supporter to witness and then to opponent on account of the violent incursions, executions and material destruction in an adjacent community. On Maco, Sendero forces arrived in ever-greater numbers, sometimes more than 60 at a time. They demanded food and ransacked the health post. They harangued people for hours demanding they block roads and blow up bridges to stop the military from entering the valley (this being an important north-south routeway for Sendero cadres). They maltreated Antonio, accusing him of being an informer.

\section{Cautiously, Antonio and other community} leaders organised resistance. But this was tricky, as they could not tell who supported Sendero, especially among the young men returning from secondary school in the towns who were no longer submissive towards their fathers. The leaders adopted a tactics of mobility, keeping on the move and sleeping in different houses. In 1991, in an attempt to turn the tide against the insurgency, the Government of Alberto Fujimori offered to arm rural settlements and district towns so the population could organise their own defence. The contours and framing of legitimate violence were changing once more. Antonio was part of the delegation sent to the army base in Tarma town to negotiate permission to form a ronda campesina (peasant militia). The ronda was in full swing when I went back to Maco in the mid1990s (Ronsbo 2006).

Every night the ronda patrolled the perimeter of the settlement, guns in hand. They captured a few delincuentes who were handed over to the military base as suspected senderistas; they also captured rustlers and trespassers who they roughed up. But the most serious threat at the messy end of the insurgency was from pishtacos. For many Andeans, pishtacos are supernatural beings who are always around, but at times of insecurity they take human form, becoming embodied as male Europeans who, nowadays, carry backpacks stuffed with knives and glass jars. On the periphery of community, between the wild and the civilised, pishtacos wait for young indigenous women, put them in a trance and using their knives cut out their fat. The fate of the women was to eventually weaken and die. In colonial times, the fat collected made Church 
candles; in the 1940s, it greased machinery of US mining companies; and in the 1980s, it went to pay the external debt. In 1994, rumours spread that pishtacos were increasing in numbers and force, for the military had issued them with licences and motorbikes. Leaders of the ronda went to Lima, demanded to see a high-ranking military officer who, bemused, assured the angry men that the military had no intention of licensing anybody to commit acts of violence! Marking the transition from conflict to 'postconflict', this military (like others) attempted to change its image, from bringing death to safeguarding life (the shift 'from guns to beans'). But in the spirals and chains of mimetic violence, this was not immediately apparent.

The pishtaco story provides a clue as to local interpretations of security. First, pishtacos represent a powerful metaphor of the inherent dangers of the external world, when white men seek to destroy the community's most precious asset, young women of reproductive age. Second, sharing stories of pishtacos was a way of unburdening fear, talking in a mode, which avoided mentioning military or Maoists. The incidence of pishtaco sightings and rapid circulation of stories gave an indication as to the fever pitch of fear. Third, by organising and arming a ronda, men demonstrated their virility and ability to defend their families and community against a supernatural threat, more powerful even than Sendero.

\section{Living with political violence and insecurity:}

Accounts of teachers who allegedly were complicit with Sendero and therefore labelled as subversives follow a similar pattern to Antonio's. They had been exposed when young to the class message of Maoism, were idealistic, searched for social justice, and felt a responsibility to 'do something' for themselves and their community. But there were also differences. Antonio's account suggests that those who came to reject Sendero put belonging, the flesh and blood ties of kinship, before abstract ideas of revolution and the cold emotion required if one was to 'cross the river of blood' as senderistas called indoctrination into political violence. It sounds almost banal that Antonio stuck to a cooperative doomed to failure rather than leave to bring down the state. Teachers who remained with the Maoist party tended to have been sent away for secondary education at a very young age. This dislocation meant they had not taken on positions of authority in the community and developed a more distanced, often nostalgic, idea of home. Teachers from communities unable to resist the onslaught of Sendero or military found themselves in the most dangerous position, as outsiders or 'tricksters' who moved their allegiance between the revolutionary alternative and repressive forces of the state. They manoeuvred in polarised fields in which they had to identify themselves as being 'for' or 'against' the insurgency, and therefore 'for' or 'against' the state. However, their encounters with violence and attempts at finding security meant in practice they transgressed distinctions of victim and perpetrator, and confounded stereotypes of political 'identity'.

Clearly, those communities which established rondas campesinas could provide better security than those who could not. But the spread of militias patrolling community boundaries indicated a hardening of boundaries as well as a shift in communal organisation that meant giving greater emphasis to masculine heroism, reinforcement of patriarchal relations and homogenising of narratives about the war. This brought contradictory implications with respect to relations in the communities themselves (Theidon 2003). The situation of many other communities was different. They were more exposed to terror tactics and threat, especially those in Sendero's so-called 'liberated' zones, forced to supply food and recruits, who then bore the brunt of violent recriminations by the military. People fled, leaving their livestock and belongings that were then confiscated by the military or aggressive neighbours. Displacement and move to the relative security of the towns changed the political as well as the social and economic landscape of the region.

\section{Afterword}

In the aftermath of insurgency, authoritarianism and corruption reached unprecedented levels in Peru. The population continued to be held under strict (wartime) surveillance by the Fujimori Government; suspected unruly groups, especially students and unionists, were hounded and their organisations prohibited. The scandals surrounding the Government's gross abuse of power, as well as its deals with drug traffickers and arms traders finally led to Fujimori's downfall in 2001. Subsequently, two tendencies 
have been prominent. One is the explosion of criminality and delinquency that has pressed some to advocate 'el mano duro' (the iron hand), whether exercised by the state or by a militarised organisation like Sendero. The other is the upwelling of political confrontations, with

\section{Notes}

1 I employ the term 'community' to indicate a rural collectivity having legal rights to land on a collective basis and an organisational structure to manage them. Settlements in the community may be concentrated or dispersed.

2 This number was given by Gloria Helfer, when Minister of Education, quoted by McGlintock (1998).

\section{References}

Ansión, Juan (1989) La Escuela en la Comunidad, Lima: Food and Agriculture Organization (FAO)

Degregori, Carlos Ivan (1991) 'How Difficult it is to be God', Critique of Anthropology 11.3

Drinot, Paulo (2006) 'Nation-building, Racism and Inequality: Institutional Development in Peru in Historical Perspective', ch. 1 in John Crabtree (ed.), Making Institutions Work: Democracy, Development and Institutions Since 1980, London: Institute for the Study of the Americas 5-23: 9

Geschiere, Peter and Meyer, Birgit (1998) 'Globalisation and Identity: Dialectics of Flows and Closure', Development and Change 29.4: 601-16

Kaldor, Mary and Luckham, Robin (2001) 'Global Transformations and New Conflicts', IDS Bulletin 21.2: 48-69

Kruijt, Dirk (2008) Guerrillas: War and Peace in Central America, London: Zed Press

McClintock, Cynthia (1998) Revolutionary Movements in Latin America: El Salvador's FMLN protesters risking the label of 'terrorist' in an attempt to protect their communities from the ravages and abuses of the mining companies, which have greatly expanded their operations in the Andes, with full support from the Government.

3 The name of the teacher has been changed.

4 Labour struggle on Maco had been intense in the 1940s. For this earlier history, see Wilson (1986).

and Peru's Shining Path, Washington DC:

United States Institute of Peace Press: 273

Ronsbo, Henrik (2006) 'Displacing Enigma and Shaping Communal Hegemony - Towards the Analysis of Violent Experience as Social Process', Dialectical Anthropology 30.1/2: 147-67 Scheper-Hughes, Nancy and Bourgois, Philippe (2004) 'Introduction: Making Sense of Violence', ch. 1 in Nancy Scheper-Hughes and Philippe Bourgois (eds), Violence in War and Peace: An Anthology, Oxford: Blackwell: 1, 19 Theidon, Kimberly (2007) 'Gender in Transition: Common Sense, Women and War', Journal of Human Rights 6: 453-78

Theidon, Kimberly (2003) 'Disarming the Subject: Remembering War and Imagining

Citizenship in Peru', Cultural Critique 54: 67-87

Wade, Peter (2000) Music, Race and Nation,

Chicago: University of Chicago Press: 3 Wilson, Fiona (1986) 'Conflict on a Peruvian Hacienda', Bulletin of Latin American Research 5.1: 65-94 